\title{
LAUGHTER AFTER TEARS: SITTING FOR AMERICAN HUMORS IN INDONESIAN SOFAS (Subtitling Humors of a Tv Serial Friends)
}

\author{
Gusti Nyoman Ayu Sukerti and Yazid Basthomi
}

State Polytechnic of Bali and State University of Malang

\begin{abstract}
The study reported in this paper aims to analyze the possible strategies used in the subtitling of the first five episodes (season 1) of Friends to render the episodes' humorous dialogues. It examines the subtitler's strategies in preserving both the semantic and humorous genes of laughter intended by the original humor. The analysis takes into account the internal and external structures of humors both in the target and source language. Choosing a subtitling strategy involves a decisionmaking process where the internal and external factors come into play and, therefore, rendering humors in a contextually bound medium, such as subtitling, does not necessarily work in the TL environment in a consistent manner. The inconsistency highlights the fact that humors, even those considered universal, are not digested in the same manner across cultures.
\end{abstract}

Keywords: subtitling strategies, humor, general theory of verbal humor (GTVH), a script-based theory for humor translation in subtitling.

\begin{abstract}
Abstrak: Penelitian ini bertujuan untuk menganalisis strategi yang mungkin digunakan oleh penerjemah dalam mempertahankan humor dalam dialog yang ada pada teks terjemahan (subtitle) dari lima episode pertama (season 1) dari acara Friends. Analisis ini memperhitungkan struktur internal dan eksternal teks baik dalam bahasa target maupun bahasa sumber. Tulisan ini membahas strategi penerjemah dalam mempertahankan kedua sumber semantis dan sumber tawa yang dimaksudkan oleh humor aslinya. Memilih strategi penerjemahan melibatkan proses pengambilan keputusan di mana faktor-faktor internal dan eksternal ikut bermain dan, karena itu, untuk mempertahankan humor dalam media yang terikat konteks, seperti subtitling, terdapat variasi cara. Variasi ini menunjukkan fakta bahwa humor tidak dipahami dengan cara yang sama di seluruh budaya. Hal ini bahkan juga terjadi pada humor yang berada dalam kategori humor universal.
\end{abstract}

Kata Kunci: strategi penerjemahan, teori umum humor verbal, teori humor berbasis teks

The present study examines transcripts containing humorous dialogues found in the TV serial Friends and their subtitled version in Indonesian as the objects of the analysis. As this study deals with two different cultural contexts (international), it falls into the category of 
macro-translational research (Gentzler, 2011). Since it delves into translational issue of Audio Visual Media (ATV), it addresses a relatively under-researched area (Zojer, 2011) even though in all situations the object remains singular, that is, "the obtainment of meaning embedded in a source language (SL) and its transfer to a target language (TL)" (Ekpenyong, 2010:328-329). Another dimension complementary to Ekpenyong's definition has been put forth by Valdeón (2011:208), i.e., "translation is not so much about rendering an existing text into a different language, but about opening and, to some extent, creating new worlds for new audiences." Pertaining to ATV, this project focuses on the first five episodes of season 1 out of the ten seasons of Friends (Crane \& Kauffman, 1994). Friends, a sitcom about a group of Friends in the New York City borough of Manhattan, was originally broadcast from 1994 to 2004. Compared to the rest of the seasons, the researchers believe that season 1 can best represent the particular genre of humor used in Friends. This is due to the fact that the first aired season is crucially significant in determining the "special position" or specific characteristic of this TV serial. Thus, we can safely believe that every attempt has been made in order to present a distinguished style of humors that would representatively label this TV serial in its future debut on screen to win the public's audienceship. The first five episodes are qualified to be taken as the corpus of this study as they display a big number of humorous dialogues which fall into many different categories of humors. The other seasons (for instance, season 10) contain limited type of humors and are concerned more with the issue of the characters' romance.

The discussion of the relationship between humor and translation is perhaps best initiated by addressing a debate that has dominated much of humor research regarding the untranslatability of certain kinds of linguistic humor. Vandaele (2002:150) is right in saying that "humor translation is qualitatively different from "other types" of translation and, consequently, one cannot write about humor translation in the same way one writes about other types of translation. "This notion is supported by a research project done by Asimakoulas (2004) who explored the issue of the subtitling of humor into Greek of the films Airplane! (1980) and Naked Gun: From the Files of the Police Squad (1988). In his research, Asimakoulas dealt with the impact of cultural elements of humors to the process of transferring humor and its final subtitling product.

The scope of the humor theory has been broadened by Attardo. According to him and his colleague, each joke is a six-tuple, involving the parameters (or Knowledge Resources) including language, situation, narrative strategy, target, logical mechanism and script opposition (Attardo \& Raskin 1991: 297; Attardo 2002:176). In brief, this theory suggests that jokes may be broken down into six parameters, called Knowledge Resources. Attardo's theoretical framework is called General Theory of Verbal Humor (or GTVH for short) in which different knowledge resources are hierarchically organized. Bearing all the elements and contextual variables of subtitling in mind, a humor theory model of norm opposition/norm acceptance for this type of translation can be graphically represented in Figure 1. 


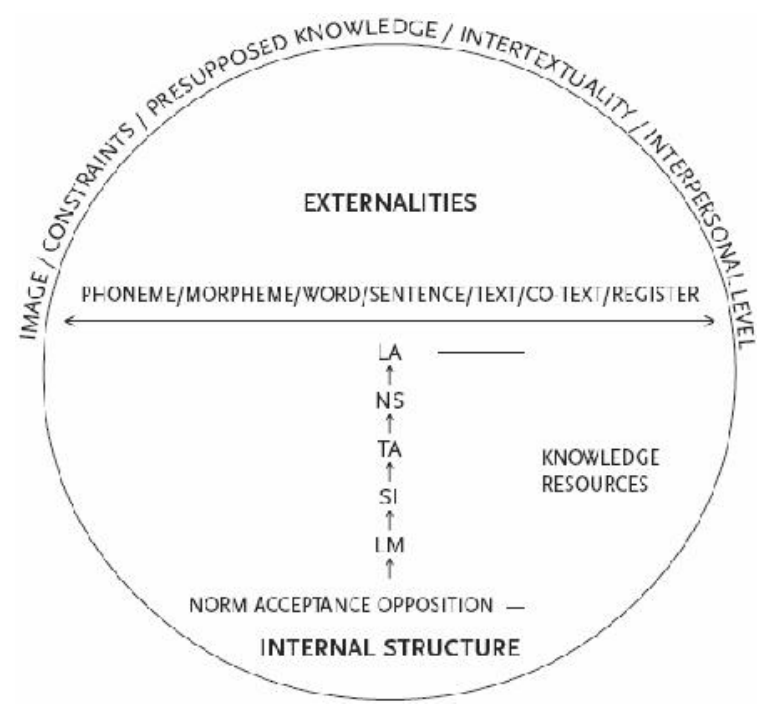

Figure 1 A Humor Theory Model of Norm Opposition/Acceptance in Translation (adopted from Attardo, 1994:232)

The contextual factors displayed in the figure (here called externalities or external structures) are a rough indication of what the context of a film might be. Image accounts for the polymedial nature of films. Certain actions, objects or entities are present on the screen and humor perception is linked to the plot unfurling on the screen. Constraints refer to what a language can do. Presupposed knowledge is a vast aspect of context and covers the encyclopedic knowledge that people possess individually or collectively, cultural assumptions, or knowledge accumulated by experiencing the world. Intertextuality is the property of texts depending upon previous instances of texts. Hatim and Mason (1990) stated that such links between texts can be held between elements of the given text as well as between distinct texts for the purpose of humor. The last contextual factor given in the figure is the interpersonal level referring to the expression of a certain attitude and feeling, as in superiority/disparagement humor and satire.

The first internal parameter (Knowledge Resources) called Script Opposition (SO) refers to the basic formula with which humor is produced. Logical Mechanism (LM) emphasizes that Logical Mechanisms will always be readily translatable from SL to TL. The reason for the ease of translatability is that non-verbal Logical Mechanisms involve fairly abstract logical-deductive processes. The third parameter, Situation (SI), gives prominence to the condition or situation in which humor takes place. The Target (TA), parameter refers to a person, group or idea being used as the target of their humor. Narrative Strategy (NS) highlights that there is little need to change the Narrative Strategy of a joke, since the ways in which the narrative is organized are language-independent. The last parameter, Language (LA), is the Knowledge Resource most directly tied to the equivalent elements of the target language compared to the source language.

The challenge of translating humor has aroused intense interest of practitioners and scholars who began to feel the need to understand its inner mechanisms and how to cope with the challenge. Some of the recent studies were conducted by Lutviana (2012) and Mikkelsen (2012). The researchers of the first study examined the failure in translating humor in humor graphic novel The Diary of a Wimpy Kid. They judged the failure in 
translating humor by recognizing whether or not the characteristic humor in the three categorization of humor (linguistic humor, cultural humor, universal humor) as well as its humorous effect is presented in the target text. The findings highlight that in translating the humorous cartoon, the translator does not preserve its nuances and atmosphere that make the humor live up. Mikkelsen (2012) asserted a similar finding when pointing out that the subtitling analysis of the movie "Clue" proved that it was of very high quality, but that the constraints of the individual subtitler play an important role in achieving the most optimal subtitling possible. Those two findings give insight to the difficult position of humor in the field of translation. Subtitling to some extent makes it difficult for humor to have a better position due to its particular constraints.

Gottlieb (1992:164) highlights two different constraints of subtitling: textual (qualitative) and formal (quantitative). Textual constraints are those imposed on the subtitling by the visual context of the film, while formal constraints are the space factor (the maximum of two lines allowed, with approximately 35 characters per line) and the time factor (time coding). The time factor, in particular, plays a pivotal role in the decisions translators have to make. As a consequence, the target language (TL) text may sometimes end up being rather minimalist, thus leading the subtitler to apply solutions that clearly state what is core and what is redundant in any specific contexts.

In light of all the previous researches, this paper emphasizes the solutions opted by the subtitler of the first five episodes (season 1) of Friends in confronting the notion of untranslatability of humor while taking into account the readability of subtitling in TL environment. The serial unveils a specific series of social and cultural characteristics of American life and people to foreign audience, i.e., Indonesian. The role of subtitling in these particular circumstances, therefore, carries a huge burden of responsibility in terms of transferring semantic, pragmatic and cultural contents. Gottlieb (1992:265) advises film translators to "give the target audience the experience they would have if they already knew the foreign language" (and, it might be added, if they already understood the source culture).

\section{METHOD}

The primary data in this study were humors found in the screenplays of the first five episodes of TV serial Friends (season 1) taken from the Internet and the recorded Indonesian subtitles for the humors presented along with the time codings and frames. The data analysis was done to find out the subtitling strategies used in translating humor with reference to Script-based Theory for Humor Translation in Subtitling by Attardo (2002). The analysis covers the following steps: (a) examining the internal structures of both the SL and TL humors to display how those two versions were hierarchically structured and rendered, (b) analyzing the external structures being transferred from the SL to TL humors to demonstrate how these structures contributed to the reproduction of humor into the TL, (c) identifying the strategies used by the subtitler in translating humor in accordance to both examination on its internal and external structures, and (d) classifying the findings based on the degree of transferability of the humor to illustrate the specific challenge in each category and type of humors. 


\section{FINDINGS}

The issue in this section revolves around the analysis of the internal and external structures of both the SL and the TL humors (referring to Attardo's framework) which then lead to the choice of strategy used by the subtitler in transferring the intended genes of laughter. The elaboration of the loss and gain in the attempts to render humorous dialogues is further discussed in the next section.

The qualitative analysis of the corpus of data used in this study is focused on how the humors are rendered into the target language and culture. Hence, the findings are broken down into three categories consisting of the linguistically-bound humor, culturally-bound humor and universal humor. The category is made on the basis of the logical mechanism and elements involved in the set up of humors. While the first two categories tend to hold up the structure of the text through literal strategy and the faithful transfer of the humorous elements (as in the case of register-based humor and allusion), the last category generally offers a solution of modifying the original structures of humors through modulation strategy.

Although some inconsistencies do arise, the findings show that the categories of humor take two different sides. The first two tend to leave the responsibility in comprehending the humors on the part of the viewers alone by preserving some cultural references and choosing a strategy that merely holds up the structure of humors but fails to give clues that may assist the viewers' comprehension. Universal humors, those which are not linguistically bound to the source language, are devoted to the viewers' side by changing perspective in seeing the original text and are likely to result in a highly readable subtitle. However, the inconsistent pattern found hinders the equivalent transfer of humors in general because the loss and gain do apply to all categories and types of humors.

\section{Strategy for Rendering Humors Based on the Degree of its Transferability}

The categories of humors made on the basis of the investigation of the first five episodes of season 1 fall into three different categories. These humors are classified based on the degree of their transferability from the SL into TL and each group constitutes different types of humors. The linguistically-bound humor covers pun and register-based humor; the culturally-bound humor includes allusionand nonsensism; and the universal humor (linguistically-less bound humor) takes account of verbal irony, sarcasm or cutting language, bull humor, disparagementand repartee. Raphaelson-West (1989:130, in Spanakaki, 2007), has also divided jokes into three main categories: linguistic jokes (e.g. puns); cultural jokes (e.g. the ethnic jokes); and universal jokes (the unexpected). She stated that by going from top to bottom, following the above order, "the jokes are progressively easier to translate."

\section{Linguistically-Bound Humors}

Humors that fall into this category carry a distinctive burden to the process of translation through their typical set up in twisting one specific aspect of linguistics, namely, phonology. The humors manipulate phonological features of the source language (SL). This feature is highly dependent on the SL; consequently, the equivalent sounds or words delivering the equivalent intended laughing effects are sometimes nonexistent in the target language (TL). This particular pattern challenges the subtitler's competence in locating some possible options that might well serve the TL audience with the same effects of 
laughter. The study reveals that the element of twisting phonological feature is found in the form of pun and register-based humor.

Pun has become one kind of many obstacles likely to be faced in the process of humor reproduction in different language(s). Attardo (1994) points out that puns have been one of the few "debatable" aspects in the relationship of linguistics and humor studies. Wordplay, or punning, was defined broadly by Delabastita (1996:128) as "textual phenomena" contrasting "linguistic structures with different meanings on the basis of their formal similarity" (emphasis original). This type of humor indicates how language varieties can be manipulated to create humorous effects, perhaps one of the intractable problems for the subtitler. The second type of humor, register-based humor, is an instance of sociolect, or "language varieties typical of the broad groupings that together constitute the "class structure' of a given society" (Hervey \& Higgins, 1992:118). Table 1 illustrates the strategies applied by the subtitler in rendering humors belonging to the category of linguistically-bound humor.

Table 1 Strategies for Rendering Linguistically Bound Humor

\begin{tabular}{|c|c|c|}
\hline Category of Humors & Strategies & Humorous Effect \\
\hline a. Pun & $\begin{array}{l}\text { 1. Literal translation, pun is rendered into } \\
\text { another rhetorical device (another type of pun) } \\
\text { 2. Literal translation, pun is rendered into non } \\
\text { pun (preserving only one sound) } \\
\text { 3. Modulation, pun is rendered as zero pun }\end{array}$ & Misleading humorous point \\
\hline
\end{tabular}

Less humorous

b. Register-based humor

\author{
1. Modulation and condensation, the dialect is not \\ rendered
}

2. Literal translation, the register is lost
Equally transferred

Equally transferred

To provide a specific example of the subtitler's strategies, Excerpt 1 represents one of the most classical forms of vertical punning, that is, homophony produced by phonologically twisting the words "omnipotent" and "an impotent." This example describes the source language (SL) i.e., the original script followed by the target language (TL) i.e., the Indonesian subtitle. 


\section{Excerpt 1. Dialogue with Pun}

\begin{tabular}{|c|c|c|}
\hline SL & Monica: & Alright. Phoebe? \\
\hline TL & Monica : & Baiklah, Phoebe \\
\hline SL & Phoebe & $\begin{array}{l}\text { Okay, okay. If I were omnipotent for a day, I would want, um, world } \\
\text { peace, no more hunger, good things for the rain-forest...And } \\
\text { biggerboobs! }\end{array}$ \\
\hline TL & Phoebe : & $\begin{array}{l}\text { Jika aku impoten sehari saja, aku ingin perdamaian dunia... } \\
\text {...hal-hal baik untuk hutan hujan dan bokong yang lebih besar! }\end{array}$ \\
\hline SL & Ross: & Yeah, see.. you took mine. Chandler, what about you? \\
\hline TL & Ross : & $\begin{array}{l}\text { Kau mengambil keinginanku } \\
\text { Chandler, bagaimana denganmu? }\end{array}$ \\
\hline SL & Chandler: & $\begin{array}{l}\text { Uh, if I were omnipotent for a day, I'd.. make myself omnipotent } \\
\text { forever. }\end{array}$ \\
\hline TL & Chandler: & $\begin{array}{l}\text { Jika aku impoten untuk sehari, aku jadikan diriku impotent } \\
\text { selamanya }\end{array}$ \\
\hline SL & Rachel: & $\begin{array}{l}\text { See, there's always one guy. (Mocking) "If I had a wish, I'd wish } \\
\text { forthree more wishes." }\end{array}$ \\
\hline $\mathrm{TL}$ & Rachel: & $\begin{array}{l}\text { Selalu saja ada yang begitu, Jika aku punya satu permintaan... } \\
\text {...aku ingin punya } 3 \text { permintaan lagi }\end{array}$ \\
\hline $\mathrm{TL}$ & All & $\begin{array}{l}\text { Joey. Hi, Hey, buddy } \\
\text { Joey, hai teman }\end{array}$ \\
\hline SL & Monica: & Hey, Joey, what would you do if you were omnipotent? \\
\hline $\mathrm{TL}$ & Monica : & Apa yang kau lakukan jika kau impoten? \\
\hline SL & Joey: & Probably kill myself! \\
\hline $\mathrm{TL}$ & Joey : & Mungkin bunuh diri \\
\hline SL & Monica: & Excuse me? \\
\hline TL & Monica : & Apa? \\
\hline SL & Joey: & Hey, if Little Joey's dead, then I got no reason to live! \\
\hline TL & Joey & $\underline{\text { Jika Joey kecil ini mati, aku tak punya alasan untuk hidup }}$ \\
\hline SL & Ross: & Joey, uh- Omnipotent \\
\hline $\mathrm{TL}$ & Ross : & $\underline{\text { Joey, aku impoten }}$ \\
\hline $\begin{array}{l}\text { SL } \\
\text { TL }\end{array}$ & $\begin{array}{ll}\text { Joey } & : \\
\text { Joey } & :\end{array}$ & $\begin{array}{l}\text { You are? Ross, I'm sorry.. } \\
\text { Kau impoten?Ross, aku ikut prihatin. }\end{array}$ \\
\hline
\end{tabular}


As the play of the words is intrinsically linked to word forms and sounds typically dependent on the SL, they cannot simply be rendered into the TL. The analysis of the pun being discussed, as shown in Table 2, will highlight the already existing gap between the two languages.

The joke is intended to elicit laughter by phonologically twisting two words having a similar sound (homophonous), i.e., omnipotent: /a:m'nıpatant/ and an impotent: / an 'Impatant / which are dependent on the SL context. The nonexistence of words having similar sound in TL results in the failures of reproducing the humor into the target language. Thus, the subtitler rendered the pun into simply a phrase, retaining one meaning of the homophonous words (impotent - impoten). The play with similar sounds, then, is lost completely and this strategy results in a huge misinterpretation that possibly gives a frown instead of laughter to the viewers.

To conclude, the humor is unsuccessfully rendered due to the use ofcratalystic logical mechanism involving words having a homophonous sound. The failure also partly accounts for the subtitler's inability in maintaining the semantic feature of the untranslatable play of sounds. In view of this perspective, the researchers suggest that both the semantic and humorous features of this pun can be preserved while at the same time taking into account the subtitling and temporal constraints. This is done by giving a clue inside the brackets (commentary solution) to introduce the different denotative meanings of the two lexicons as shown in Table 3.

The strategy of giving comments to the words supposedly having the similar sounds in the SL will aid the viewers in comprehending the intended humorous point hidden behind the homophonous sounds of the words "omnipotent" and "impotent" although it might also risk giving up the convention of subtitle as being a brief form of translation. One thing that should be kept in mind is that this solution is better than risking losing all the elements of the SL humor and generating an "abusive" subtitling. 
196 | BAHASA DAN SENI, Tahun 44, Nomor 2, Agustus 2016

\section{Table 2 The Examination of the Internal Structures of Pun}

\begin{tabular}{|c|c|c|}
\hline Internal Structures & Source Language & Target Language \\
\hline Script Opposition (SO) & $\begin{array}{l}\text { Opposition of being } \\
\text { powerful (omnipotent) and } \\
\text { powerless (impotent) }\end{array}$ & $\begin{array}{l}\text { The script opposition is nonexistent in the TL } \\
\text { since both homophonous sounds are } \\
\text { subtitled as 'impoten' from the beginning }\end{array}$ \\
\hline $\begin{array}{l}\text { Logical Mechanism } \\
\text { (LM) }\end{array}$ & $\begin{array}{l}\text { Cratylistic 'same sound equals same } \\
\text { meaning 'Logical Mechanism of puns.' }\end{array}$ & $\begin{array}{l}\text { Non existent } \rightarrow \text { The } \\
\text { equivalent homophonous } \\
\text { sounds cannot be found in the TL. }\end{array}$ \\
\hline Situation (SI) & $\begin{array}{l}\text { The six characters were having a get- } \\
\text { together time } \\
\text { in the Central Perk café and } \\
\text { imaging what they would } \\
\text { wish for if they were omnipotent for a day }\end{array}$ & $\begin{array}{l}\text { Implicitly, the situation is } \\
\text { being recreated because the } \\
\text { talk becomes no longer logical due to the } \\
\text { strategy used in subtitling the pun. }\end{array}$ \\
\hline Target (TA) & $\begin{array}{l}\text { Feature humor i.e. stupidity. } \\
\text { Joey catches the word 'omnipotent' as } \\
\text { 'an impotent'. Thus, he produces an } \\
\text { incongruous statement (the punch line) } \\
\text { that totally differs from the context of the } \\
\text { previous talking. Note that Joey appears } \\
\text { later on the scene. }\end{array}$ & $\begin{array}{l}\text { The particular target cannot be easily pointed } \\
\text { out because the subtitle produces } \\
\text { misinterpretation. Thus, every character } \\
\text { seems to speak illogically. The confusion } \\
\text { might arise because the artificial laughter is } \\
\text { not played until it reaches Joey's dialogues. }\end{array}$ \\
\hline $\begin{array}{l}\text { Narrative Strategy } \\
\text { (NS) }\end{array}$ & $\begin{array}{l}\text { Question and answer } \\
\text { dialogue }\end{array}$ & Question and answer dialogue \\
\hline Language (LA) & $\begin{array}{l}\text { Verbal humor (punning) } \\
\text { based on the phonological } \\
\text { ambiguity of the homophonous words } \\
\text { 'omnipotent' and 'an } \\
\text { impotent' } \\
\text { omnipotent : /a:m'nIpətent/ } \\
\text { an impotent : /an 'Impətent/ }\end{array}$ & $\begin{array}{l}\text { The pun is unsuccessfully rendered. Both } \\
\text { homophonous sounds intented to elicit } \\
\text { laughter are subtitled into } \\
\text { 'impoten' }\end{array}$ \\
\hline
\end{tabular}


Table 3 The Comparison of the Literal Strategy and Commentary Solution

Original Script

Monica:Alright. Phoebe?

Ross:Yeah, see.. you took mine.

Chandler, what about you?

Chandler: Uh, if I were omnipotent for a day, l'd.. make myself omnipotent forever.

Rachel:See, there's always one guy. (Mocking) "If I had a wish, I'd wish forthree more wishes."

All: Joey. Hi. Hey, buddy.

Monica:Hey, Joey, what would you do if you were omnipotent?

J oey:Probably kill myself!

Monica:Excuse me?

Monica: Hey, Joey, what would you do if you were omnipotent?

J oey: Hey, if Little Joey's dead, then I got no reason to live!

Ross:Joey, uh- Omnipotent J oey :You are? Ross, I'm sorry..

\section{Subtitler's Strategy (Literal Strategy) Altemative Strategy (Commentary Solution)}

Baiklah, Phoebe

Kau mengambil keinginanku

Chandler, bagaimana denganmu?

Jika aku impotent untuk sehari, aku

jadikan diriku impotent selamanya

Selalu saja ada yang begitu, Jika aku punya satu permintaan...

...aku ingin punya 3 permintaan lagi

Joey, hai teman

Apa yang kau lakukan jika kau impotent?

Mungkin bunuh diri

Apa?

What?

Apa yang kau lakukan jika kau impotent?

Jika Joey kecil ini mati, aku tak punya alasan untuk hidup

Joey, aku impoten

Kau impotent?

Ross, aku ikut prihatin.
Baiklah, Phoebe

Kau mengambil keinginanku

Chandler, bagaimana denganmu?

Jika aku omnipotent untuk sehari, aku jadikan diriku omnipotent selamanya

Selalu saja ada yang begitu,

Jika aku punya satu permintaan... ...aku ingin punya 3 permintaan lagi

Joey, hai teman

Apa yang kau lakukan jika kau omnipotent?

Mungkin bunuh diri

Apa?

What?

Apa yang kau lakukan jika kau omnipotent?

Jika Joey kecil ini mati (impoten), aku tak punya alasan untuk hidu

Joey, aku omnipoten (mahakuasa)

Kau impoten?

Ross, aku ikut prihatin 


\section{Culturally-Bound Humors}

This group shows two types of humors that contain some associations of cultural or allusive references to something outside the context of speaking. This particular type can be said as sharing a degree of common characteristics with the types of humors that fall under the category of linguistically-bound humor because it possibly gives intricacy to the transferring process of the SL humors. This research uncovers allusion and nonsensism as the types of humors which represent the existence of cultural elements in the logical mechanism of the jokes. As allusions are culturally-bound, the degree to which they are comprehensible across the barriers of culture and language varies to a great extent. The sources of allusions, such as, history, literature, cinema and television, are rarely familiar beyond their cultures of originbecause popular culture seems to travel more extensively than high culture. "American television serials and films may be an exception to this phenomenon, but they will serve to emphasize the fact that cultural products seem to be crossing borders in one direction only" (Spanakaki 2007: par. 10). Nonsensism includes all kinds of absurdity without realistic logic and makes a general observation of absurd reference. It includes virtually every kind of absurdity from mock logic to fantastic common sense, and a variety of fallacies without any reason.

Excerpt 2 is shows a model of nonsense statement covered up with the mechanism of pragmatic ambiguity and allusive reference. This mechanism provides the subtitler with more than just a task of rendering the humorous genetic element; he/she also holds responsibility in relocating the other two supplementary components because all those three features of the humor are internally related.

\section{Excerpt 2 Dialogue with Nonsensism}

SL

(Rachel runs up clutching an envelope.)

Rachel: Look-look-look-look-look, my first pay check! Look at the window, there's my name! Hi, me!

TL Rachel: Lihat! Cek gaji pertamaku! Lihat di jendelanya! Itu namaku!

SL

TL Phoebe : Aku ingat waktu pertama kali aku mendapat gaji. Phoebe: Iremember the day I got my first pay check. There was a cave in one of the mines, and eight people were killed. Ada tambang yang runtuh dan 8 orang tewas.

SL Monica: Wow, you worked in a mine?

TL Monica: Kau bekerja di tambang?Tidak.

SL Phoebe: I worked in a Dairy Queen, why?

TL Phoebe: Aku bekerja diDairy Queen. Kenapa? 
The correlation of those three components can be closely examined through the analysis of the humor's internal structures as shown in Table 4.

Table 4 Examination of the Internal Structures of Nonsensism (Ex. 2)

\begin{tabular}{lll}
\hline The Internal Structures & Source Language & Target Language \\
\hline Script Opposition (SO) & Relevant versus irrelevant & Unchanged \\
Logical Mechanism (LM) & $\begin{array}{l}\text { Absurdity in the line of pragmatic ambiguity and } \\
\text { allusion }\end{array}$ & Unchanged \\
Situation (SI) & Phoebe refers to her first paycheck day & Unchanged \\
Target (TA) & Phoebe & Unchanged \\
Narrative Strategy (NS) & Dialogue & Unchanged \\
Language (LA) & $\begin{array}{l}\text { Firstly, a hackneyed frame ('I remember...') is } \\
\text { used, but Phoebe then flouts expectations, }\end{array}$ & Unchanged \\
& $\begin{array}{l}\text { stretching this frame and producing a ludicrous } \\
\text { expansion of irrelevant and an absurd portrayal } \\
\text { of a terrible accident in a mine. She gave an } \\
\text { unexpected end (hence the funny incongruity) }\end{array}$ & \\
& $\begin{array}{l}\text { suggesting that she did not actually work in the } \\
\text { mine }\end{array}$ & \\
\hline
\end{tabular}

Surprisingly, the essence of laughter on this particular joke is safely rendered into the target language without any violation on the constraints of subtitling, apart from the fact that it consists of three different levels of elements including absurdity, pragmatic ambiguity, and allusion as illustrated in the following examination:

1. absurdity: the irrelevant reference of terrible accident is created to describe Phoebe's first day of paycheck. It flouts the normal expectation that the day should be described in a positive manner or linked to a joyous event.

2. - pragmatic ambiguity:

a) Phoebe's failure in understanding the contextual situation (Rachel is being extremely excited in receiving her first paycheck) gives chance for the absurd and irrelevant reference to appear.

b) Phoebe's last utterance, particularly when she innocently questions "why?", is the unexpected end suggesting that she fails to relate the fact that her reference should have been made to her first job in the Dairy Queen (not in a mine).

3. allusion: the punch line stated in the last statement also makes use of an allusive reference to 'Dairy Queen' (the place where Phoebe worked) as an opposition to her previous absurdreference.

The internal structures of both the SL and TL humor indicate that no change has been made. This means that the subtitler's strategy is literal translation in which all linguistic features are transferred faithfully into the target language with only a minor deletion of a phrase "Hi, me!". Apparently, the "non-translatable" element is only the allusive reference Dairy Queen which is characteristically specific to the source language. In preserving the 
allusion as it is, the subtitler does not consider the viewers' intertextuality into account, assuming that the viewers can make an independent inference through the context of Phoebe's answer. However, in referring to the strategy applied by the subtitler in dealing with the previous allusions setting up the first example of nonsensism, the subtitler might well adapt the same strategy of translating "Dairy Queen" into 'pabrik olahan susu' meaning "factory of dairy product" as the alternative solution. This way, the viewers can fully grasp the contradiction and are free from the need to use their competence in intertextually relating the allusion. Fortunately, the smooth transfer of the other two elements, i.e., absurdity and pragmatic ambiguity cover up the misinterpretation potentially produced by this non-translatable allusion.

Table 5 summarizes the strategies used by the subtitler in rendering the culturally bound humor in the serial and the effect of the strategies.

Table 5 Strategies for Rendering Culturally Bound Humor

\begin{tabular}{lll}
\hline Category of Humors & Strategies Employed & Humorous Effect \\
\hline a. Allusion & $\begin{array}{l}\text { Literal translation, the allusion is transferred } \\
\text { through imitation }\end{array}$ & Less humorous \\
& &
\end{tabular}

b. Nonsensism

1. Condensation and literal translation,

Equally transferred the allusions are either deleted, reduced, or imitated as it is

2. Literal translation

3. Condensation and literal translation, the alliteration is compensated in other point

4. Literal translation with a minor deletion, the allusion is kept as it is

Equally transferred

Equallytransferred

Equally transferred

\section{Universal Humor}

The last category of humor and its degree of transferability is characterized by its relatively free union to any linguistic components which tend to be highly dependent on the source language. This makes it possible for many different types of humors to be put under this category because they are unlikely to trigger any misleading information or misconceptions when they come to a wide range of uses and audience. Types of humors belonging to this universal humors are verbal irony, sarcasm, bull humor, repartee, insult humor, and disparagement.

Mateo (1995:172) states: "irony depends on context, since it springs from the relationships of a word, expression or action with the whole text or situation." The second type of humors belonging to this category, sarcasm, refers to a humor that is both cutting and bold in a mocking fashion. Sarcastic humors would never be described as gentle or appealing, but rather as razor-sharp and bitter-describing situations, persons, or things in a disparaging way in order to be funny. Bull humor is a humorous statement based on an 
outrageous contradiction.It is one of the most frequent types of humors engaged for the purpose of provoking laughter in the mind of the audience.

Disparagement or superiority humor presupposes a norm acceptance, a presupposed cultural convention, or norm opposition, that is, degrees of acceptability when it is used in certain contexts. The last type of humor, repartee, is a branch of wit that covers clever replies and retorts including insult, double insult, reversible and parallel.

Excerpt 3 (taken from the second episode) shows that a choice of modulation strategy chosen by the subtitler can only render the semantic meaning safely, but fails to give the same humorous effect. This example "proves" that literal translation can render both the semantic meaning and the humorous effect equivalently into the target language. This is made possible due to the fact that the language used in the original script does not contain any linguistic element specific to the SL that may impede the effort in producing a natural subtitle in TL.

\section{Excerpt 3 Dialogue with Bull Humor}

SL Mr. Geller: I'm not gonna tell you what they spent on that wedding...

TL Mr. Geller: $\quad$ Ayah tak mau memberitahukan berapa uang yang... mereka habiskan untuk pernikahan itu tapi...

SL Mr. Geller : $\quad$...but forty thousand dollars is a lot of money!

TL Mr. Geller : $\quad \ldots \$ 40.000$ itu bukan jumlah yang sedikit.

This humor does not fully maintain the original structure through literal translation; instead, modulation is chosen to render the punch line of the joke as shown by the modification on the internal structure of the TL language. The analysis of the internal structure is presented in Table 6.

Table 6 Examination of Internal Structures of Bull Humor

\begin{tabular}{lll}
\hline The Internal Structures & Source Language & Target Language \\
\hline Script Opposition (SO) & Relevant versus irrelevant & Unchanged \\
Logical Mechanism (LM) & Violation on the maxim of quality & $\begin{array}{l}\text { Logical mechanism can be } \\
\text { easily found }\end{array}$ \\
Situation (SI) & $\begin{array}{l}\text { Mr. Geller was talking about Rachel's } \\
\text { expensive wedding party that turned out } \\
\text { to be a disaster }\end{array}$ & Unchanged \\
Target (TA) & Mr. Geller & \\
Narrative Strategy (NS) & Short narrative & Unchanged \\
Language (LA) & Explicit negation to one's own statement & $\begin{array}{l}\text { The language is changed into } \\
\text { an implicit negation to one's }\end{array}$ \\
& own statement through the use \\
& & of double negation
\end{tabular}


This humor also places its humorous gene in the power of illogical contradiction that, in this case, is indicated by the use of conjunction "but". In the contextual condition of this joke, "but" as the introductory conjunction is used to introduce a clause or a new statement that adds information such as background or reasoning. This conjunction is manipulated in such a way that the utterance stated in the first clause is perceived as a pointless statement. An example of a congruous constructed statement might sound like "Sandy isn't coming with us, but she doesn't like romantic movies anyway".

As shown in Table 7, the modulation strategy used in translating the punch line (marked by the italic format) does render the explicit negation on the part of the speaker's statement, but does not provide enough reason for employing such a strategy. Bearing in mind that the original humor contains an explicit negation that makes the speaker violate his own maxim of quality, the modulation strategy results in a more implicit statement particularly in the second clause because it converts a positive construction for a negative construction. The researchers suggest that the subtitler opt for the literal translation as the alternative strategy (see Table 7). The choice of modulation, compared to the literal strategy, shows that it does not hold up the humorous effect intended by the original contradictory statement (the SL humor) because the process of modulation gives a euphemistic sense to the target utterance. This euphemism affects the incongruity of the original humor and reproduces a less humorous humor in the target language. Although the modulation strategy does confirm that the speaker violates the maxim of quality "of not going to tell the amount of money spent on the wedding" by stating the exact amount of money on the second statement, the euphemism blocks the effect of explicit contradiction because to some degree, the negative statement still goes in line with the first statement.

Table 7 The Comparison of the Modulation Strategy and Literal Strategy

\begin{tabular}{|c|c|c|}
\hline Original Script & $\begin{array}{l}\text { Subtitler'sStrategy (Modulation } \\
\text { Strategy) }\end{array}$ & Alternative Strategy (Literal Strategy) \\
\hline $\begin{array}{l}\text { Mr. Geller: I'm not gonna tell } \\
\text { you what they spent on that } \\
\text { wedding... but forty thousand } \\
\text { dollars is a lot of money! }\end{array}$ & $\begin{array}{l}\text { Ayah tak mau memberitahukan berapa } \\
\text { uang yang mereka habiskan untuk } \\
\text { pernikahan itu tapi } \$ 40.000 \text { itu bukan } \\
\text { umlah yang sedikit. }\end{array}$ & $\begin{array}{l}\text { Ayah tak mau memberitahukan berapa } \\
\text { uang yang mereka habiskan untuk } \\
\text { pernikahan itu tapi } \$ 40.000 \text { adalah uang } \\
\text { yang sangat banyak }\end{array}$ \\
\hline
\end{tabular}

Modulation strategy:

(implicitly stating that the wedding costs a lot of money through the use of negation bukan "not" + sediki t"a little" meaning banyak"much")

Literal strategy:

(explicitly stating that the wedding costs a lot of money through the use of the quantitifersangat banyak "a lot of")

To sum up, the strategies utilized by the subtitler in rendering bull humor which is basically characterized by the mechanism of outrageous contradiction does not yet successfully result in natural Indonesian subtitles although it can still be acceptable and digestible. Table 8 shows how the six types of humors are rendered into the target language. 


\section{Table 8 Strategies for Rendering Universal Humor}

\begin{tabular}{|c|c|c|}
\hline Category of Humors & Strategies & Humorous Effect \\
\hline \multirow[t]{3}{*}{$\begin{array}{ll}\text { a. } & \text { Verbal } \\
\text { Irony }\end{array}$} & $\begin{array}{ll}\text { 1. } & \text { Literal translation } \\
\text { 2. } & \text { Literal translation and } \\
& \text { modulation (on the punch line) } \\
\text { 3. } & \text { Modulation and literal strategy } \\
\text { (on the punch line) } \\
\text { 4. } & \text { Modulation }\end{array}$ & $\begin{array}{l}\text { Equally transferred } \\
\text { Equally transferred }\end{array}$ \\
\hline & & Equally transferred \\
\hline & & $\begin{array}{l}\text { Equally transferred, only less } \\
\text { formal }\end{array}$ \\
\hline \multirow[t]{3}{*}{ b. Sarcasm } & 1. Literal translation & Less humorous \\
\hline & 2. Modulation strategy & Equally transferred \\
\hline & 3. Addition strategy & Equally transferred \\
\hline \multirow[t]{4}{*}{ c. Bull Humor } & 1. Modulation & $\begin{array}{l}\text { Equally transferred but less } \\
\text { humorous }\end{array}$ \\
\hline & 2. Literal translation with a & Equally transferred \\
\hline & minor deletion & \\
\hline & 3. Literal translation & $\begin{array}{l}\text { Equally transferred, only } \\
\text { results in an awkward } \\
\text { translation }\end{array}$ \\
\hline d. Disparagement & Literal translation & Equally transferred \\
\hline \multirow[t]{2}{*}{ e. Repartee } & 1. Modulation & $\begin{array}{l}\text { Equally transferred, but less } \\
\text { humorous }\end{array}$ \\
\hline & $\begin{array}{l}\text { 2. Modulation (on the punch line) } \\
\text { and literal translation }\end{array}$ & Equally transferred \\
\hline
\end{tabular}




\section{DISCUSSION}

\section{Loss and Gain in Rendering Humorous Dialogues}

Translating humors challenges subtitler's creativity in transferring the core of laughter into the target language. An interesting view was stated by Vandaele in emphazising the core problem of humor translation. Vandaele (2010:150) stated that the particular problem with humor translation is that humor relies on implicit knowledge. Moreover, groups may have different agreements on what or whom can be targeted in social play. In other words, humor depends on implicit cultural schemes (to be breached for incongruous purposes; to be known for the purpose of comical "solution") and has its rules and taboos for targeting (telling what or whom may be laughed at). In the TV serial Friends, changing the structure of the difficult humorous sequence, to some degree, proves to be an effective solution. Still, the inconsistencies, moderating the level of humor and some inappropriateness found cannot only be attributed to the difficulty of rendering humor in a distinct way. The linguistic element dependent on the source language poses a significant obstacle in finding not only its equivalent semantic feature but also its laughing matter in the target language.

The inconsistencies found in the attempt of rendering humors belonging to the same category or type also highlights the fact that one strategy does not always prove to be the best solution in dealing with the same problem. These inconsistencies are made possible because each humor is constructed by different elements, meaning that the subtitler is forced to "take sides" in deciding on the solution that best keeps the laughing effect. A translator mostly has to choose one of the three sides (Nida, 2000:127). The first side is the writer's side, meaning that the translator will try to conserve most of the original messages and sacrifices the readers' understanding of the whole text. The second one is the text's side, meaning that the translator strives to maintain the original form of the source text, neglecting the underlying message of the writer as well as the understanding of the target readers. The last perspective dictates that prominence goes to the readers' side, meaning that the translator attempts to transfer the message of the text with priority given to the understanding of the target readers of the message implied in the text. The problem is that whatever side a translator chooses, the possible consequence that likely to follow is the loss of a certain degree of the internal elements of the SL humor or the sacrifice of one of its external elements.

Across the three categories of humors, literal translation as opposed to the other strategies is more frequently used on the basis of assumption that the intertextuality of the viewers is not taken into a serious consideration. This condition results in the loss of humorous point or produces less humorous humors in the TL. This case can be traced back in the process of rendering humors made on the basis of manipulating some allusive references and humors based on the contradictory logical mechanism. Fortunately, the external structures, be they in the form of image (paralinguistic codes and kinetic signs) or interpersonal level support the reproduction of humor and to some degree help cover up the loss. However, the choice of translating the humors literally (in some cases of sarcasm, verbal irony, bull humor, repartee and disparagement) has proved to be the best solution in the way that it does not only preserve the humorous effect but also produce subtitles with a high degree of readability in the target language.

The second most frequently applied strategy, i.e., modulation, is applied particularly in the transferring process of repartee involving the procedure in which the subtitler changes 
the category of thought or offers a different perspective by restructuring the SL humor. This strategy, in some cases, aids the viewers to comprehend and experience the humor naturally in their native language. But again, this does not apply to all cases because changing the category of thought by providing "negative" for "positive" statement (a case of bull humor) affects the logical mechanism of the TL humor and results in an implicit and less humorous contradiction.

All in all, the elaboration presented in the previous point has given us a way to see that far from being an "impossible" task, if the number of strategies are chosen thoroughly and implemented appropriately, they allow for successful translations. To put it in the perspective of the old notion of "loss versus gain", the particular stage of inconsistency found here shows that, while something is inevitably lost in the complex process of translation, quite a lot is gained - or at least preserved and recreated. More in general, it may also be underlined that unlike dubbing, its "freer" Audiovisual Translation relative, subtitling is still devoted to the tendency of transferring the elements of the source script more closely from a semantic point of view. It can be argued that by reproducing the denotative meaning of the humorous dialogue, subtitlers tend to minimize the risk of clashes with the visual content of the program particularly the characters' paralinguistic codes (tone of speech, stress) and kinetic signs (gestures and facial expressions). Thus, the literal strategy is frequently chosen in the process of rendering humor, although the overall findings present the existence of inconsistent pattern.

\section{CONCLUSIONS}

The inconsistency of pattern found in this research shows that the choice of strategy does not merely depend on the similarity shared by the humors, but the prominence goes to the distinctive characteristics of each humor in relation to the structure of its internal and external elements. The inconsistency then further highlights that humors are not accepted or digested in the same way across cultures even those included under the category of universal humor. This finding could well guide us to believe that linguistic differences alone are an obstacle to an equivalent humor response across cultures. If this is true, and to conclude with a rather provocative stance, it might be agreeable that actually the answer to the appreciation of translated humor on screen depends on the matter of the quality of translation. To be precise, instead of being subjected to the debate of whether to opt for a movement from the viewer to the film (foreignizing strategy) or from the film to the viewer (naturalizing strategy), the subtitler should strive to stand in a middle-ground position. Therefore, the subtitler can produce a quality translation that can both equally transfer the core of laughter and naturally render the underlying cultural message into the target language - a job possibly implicating tears on the part of the subtitler.

The literal strategy used by the subtitler of Friends in rendering allusive references which are dependent on the source language shows that he/she has already taken a step to apply this very perspective with a risk that the viewers might lose the humors completely. Thus, to wipe off the tears, the researchers recommend that the subtitler take into account the diversity of the viewers' intertextuality by giving an alternative yet unconventional strategy, i.e., commentary solution in some possible cases of cultural or untranslatable humors while still considering the existence of the subtitling constraints. 


\section{REFERENCES}

Asimakoulas, D. 2004. Towards a Model of Describing Humour Translation: A Case Study of the Greek Subtitled Versions of Airplane! and Naked Gun. META,49 (4):822-842.

Attardo, S. 1994. Linguistic Theories of Humour. Berlin: Mouton de Gruyter.

Attardo, S. 2002. Translation and Humor: An Approach Based on the General Theory of Verbal Humour (GTVH). The Translator, 8 (2): 173-194.

Attardo, S., \& Raskin, V. 1991. Script Theory Revis(it)ed: Joke Similarity and Jokes Representation Model. Humor: International Journal of Humor Research. 4 (3-4): 293347.

Crane, D., \& Kauffman, M. 1994. Friends [Television broadcast]. Burbank, California. United States: Warner Bros Television.

Delabastita, D. 1996. Introduction: In Wordplay and Translation. The Translator, 2 (2): 127-139.

Ekpenyong, E. 2010. Translating and Interpreting: One Object, Different Approaches. Babel. 56 (4): 328-340. doi 10.1075/babel.56.4.03ekp.

Gentzler, E. 2011. Macro- and micro-turns in translation studies. Translation and Interpreting Studies. 6 (2): 121-141. doi 10.1075/tis.6.2.01gen.

Gottlieb, H. 1992. Subtitling - ANew University Discipline. In Teaching Translation and Interpreting: Training, Talent and Experience. Papers from the First Language International Conference, Elsinore, Denmark 31 May-2 June 1991 (161-170). Amsterdam/Philadelphia: John Benjamins Publishing Company.

Hatim, B., \& Mason, I. 1990. Discourse and the Translator. London:Longman.

Hervey, S., \& Higgins, S. 1992. Thinking Translation. A Course in Translation MethodFrench and English. London and New York: Routledge.

Lutviana, R. 2012. The Failure in Translating Humor: A Case Study in the Indonesian Translation of Humor Graphic Novel-The Diary of a Wimpy Kid. Thesis. Malang: Universitas Negeri Malang.

Mateo, M. 1995. The Translation of Irony. META. 40 (1): 171-178.

Mikkelsen, L.M.S. 2012. The Challenges of Subtitling H umor with the M ovie "Clue" as an Example. Unpublished Thesis. Aarhus: Aarhus University.

Nida, E. 2000. Principles of Correspondence. In L. Venuti (Ed.), Translation Studies Reader (126-140). London and New York: Routledge.

Spanakaki, K. 2007. Translating Humor for Subtitling. Translation Journal, 11(2). (Online), (http://translationjournal.net/journal/40humor.htm)

Valdeón, R.A. 2011. On Fictional Turns, Fictionalizing Twists and the Invention of the Americas. Translation and Interpreting Studies. 6 (2): 207-224. doi 10.1075/tis.6.2.06val.

Vandaele, J. 2002. Introduction:(Re-) Constructing Humour-Meanings and Means in Translating Humour. The Translator Journal. 8 (2): 149-172.

Vandaele, J. 2010. Humor in Translation. In Y. Gambier and L.v. Doorslaer (Eds.),Handbook of Translation Studies. (Vol. 1) (147-152). Amsterdam/Philadelphia: John Benjamins Publishing Company.

Zojer, H. 2011. Cultural References in Subtitles: A Measuring Device for Interculturality? Babel. 57 (4): 394-413. doi 10.1075/babel.57.4.02zoj.

Script of Friends (Online), (http://www.friendscafe.org/scripts/s1.php) 